\title{
GAKUSHUIN \\ NATURAL RADIOCARBON MEASUREMENTS IV
}

\author{
KUNIHIKO KIGOSHI and HIROMI KOBAYASHI
}

Faculty of Science, Gakushuin University, Mejiro Toshimaku, Tokyo, Japan

This list includes many of the datings done from November 1963 to October 1964. The instruments and techniques used for this work are essentially the same as those used previously (Gakushuin III).

Age calculations are based on the Libby half life of $\mathrm{C}^{14}, 5570 \pm 30 \mathrm{yr}$. The errors quoted are the standard deviation obtained from the number of counts only. When observed activities are less than $2 \sigma$ above background, infinite dates are given with a limit corresponding to the activity of $3 \sigma$, and when they are greater than the activity of $95 \%$ of NBS oxalic-acid standard minus $2 \sigma$, modern dates are given with the limit equal to $3 \sigma$ below the $95 \%$ of NBS standard.

We wish to acknowledge the help of Tamako Morinaga and Kunihiko Endo in preparing chemical samples. The description and comments are essentially those of persons submitting the samples.

\section{SAMPLE DESCRIPTIONS}

\section{GEOLOGIC: SAMPLES}

\section{Kikai Island series, Kagoshima}

Samples from Kikai Island related to change of sealevel and dune formation. Coll. and subm. 1963 by Hideo Mii, Shimane Univ.

\section{GaK-451. Nakazato, Kikai Is. \\ $4360 \pm 140$ \\ 2410 в.c.}

Land mollsuca (Satsuma oshimae) from southern hill of Nakazato, Kikai Is., Kagoshima Prefecture ( $28^{\circ} 18^{\prime} 30^{\prime \prime} \mathrm{N}$ Lat, $129^{\circ} 55^{\prime} 50^{\prime \prime} \mathrm{E}$ Long), in ancient soil by which coastal dune bodies are divided into present and ancient ones. Comment (H.M.) : dates stoppage of migration or development of coastal dune.

\section{GaK-452. Shiramizu, Kikai Is.}

$4370 \pm 130$

2420 в.c.

Shell (Tridacna noae) from Shiramizu, Kikai Is., Kagoshima Prefecture $\left(28^{\circ} 19^{\prime} 20^{\prime \prime} \mathrm{N}\right.$ Lat, $130^{\circ} 0^{\prime} 5^{\prime \prime} \mathrm{E}$ Long). Sample from uppermost part of emerged coral reef forming an extensive terrace of $3.5 \mathrm{~m}$ above mean high water. Comment (H.M.) : date suggests beginning of a temporary halt in fall of sealevel after maximum transgression indicated by GaK-454.

GaK-453. Sekiren, Kikai Is.

Coral from Sekiren, Kikai Is., Kagoshima Prefecture $\left(28^{\circ} 19^{\prime} 10^{\prime \prime}\right.$ N Lat, $129^{\circ} 57^{\prime} 0^{\prime \prime} \mathrm{E}$ Long), near surface of emerged fringing coral reef forming a flat terrace of $3 \mathrm{~m}$ above mean high water. Comment (H.M.) : dates a temporary halt in fall of sealevel late in Holocene. 
GaK-454. Nakazato, Kikai Is.

$6630 \pm 150$

4680 в.c.

Coral from Nakazato, Kikai Is., Kagoshima Prefecture $\left(28^{\circ} 18^{\prime} 45^{\prime \prime} \mathrm{N}\right.$ Lat, $129^{\circ} 55^{\prime} 35^{\prime \prime}$ E Long), in emerged coral reef forming a terrace $7 \mathrm{~m}$ above mean high water. Comment (H.M.) : dates maximum local Holocene transgression.

\section{GaK-455. Suitengu, Kikai Is.}

Echinoid (Peronella pellucida) from E foot of Mt. Suitengu, Kikai Is., Kagoshima Prefecture (28 $18^{\prime} 10^{\prime \prime} \mathrm{N}$ Lat, $129^{\circ} 56^{\prime} 40^{\prime \prime} \mathrm{E}$ Long), imbedded in laminated calcareous beach sand unconformably underlying Holocene coral reef. Comment (H.M.) : date indicates ancient sealevel at ca. $+35 \mathrm{~m}$.

\section{GaK-381. Shimabara, 3}

$25,900 \pm 1000$ 23,950 в.C.

Wood from Harajooshi Minami-arimamachi, Nagasaki Prefecture $\left(32^{\circ}\right.$ $37^{\prime} 30^{\prime \prime} \mathrm{N}$ Lat, $130^{\circ} 15^{\prime} 30^{\prime \prime} \mathrm{E}$ Long), ca. $+5 \mathrm{~m}$, imbedded in Ōe Layer underlain by Aso Lava. Coll. 1962 and subm. by Yukio Kuwano, S. K. Kenkyusho. Comment: same sample as GaK-247 (Gakushuin III) ; good agreement.

GaK-383. Daisen, 3

$17,200 \pm 400$

15,250 в.с.

Charcoal from Shintakada, Nawamachi, Tottori Prefecture $\left(35^{\circ} 27^{\prime} 52^{\prime \prime}\right.$ $\mathrm{N}$ Lat, $133^{\circ} 30^{\prime} 30^{\prime \prime} \mathrm{E}$ Long), $35 \mathrm{~cm}$ below surface of mudflow of last (?) eruption of Mt. Daisen. Coll. and subm. 1963 by Tsurunaga Kimachi, Yonago Kita High School. Comment: same deposit as N-93, 17,710 \pm 750 (Riken I).

\section{GaK-386. Gomyodani, Tokushima}

$$
\begin{aligned}
& \mathbf{2 8 , 4 0 0} \pm 1700 \\
& \mathbf{2 6 , 4 5 0} \text { в.с. }
\end{aligned}
$$

Wood from river bed, Gomyodani, Awamachi, Tokushima Prefecture $\left(34^{\circ} 5^{\prime} 19^{\prime \prime} \mathrm{N}\right.$ Lat, $134^{\circ} 12^{\prime} 10^{\prime \prime}$ E Long), imbedded in clay overlain by Dochu gravel bed (Upper Pleistocene). Coll. and subm. 1963 by Kazumi Suyari, Iniv. of Tokushima.

GaK-388. Nanao, Ishikawa Prefecture

Wood from Tsumuki-machi Nanao City, Ishikawa Prefecture $\left(37^{\circ} 3^{\prime} 2^{\prime \prime}\right.$ $\mathrm{N}$ Lat, $136^{\circ} 55^{\prime} 10^{\prime \prime} \mathrm{E}$ Long), $3 \mathrm{~m}$ below surface of plant-fossil layer. Coll. and subm. 1963 by Norio Fuji, Univ. of Kanazawa. Comment (N.F.) : flora suggests warm climate.

\section{Kozuhata series, Shiga Prefecture}

Wood from Kozuhata, Eigenji-machi Shiga Prefecture $\left(35^{\circ} 2^{\prime} 30^{\prime \prime} \mathrm{N}\right.$ Lat, $136^{\circ} 19^{\prime} 18^{\prime \prime} \mathrm{E}$ Long), from Kozuhata cold-climate plant-fossil bed, overlain hy sediments of Younger Terrace II. Coll. and subm. 1963 by M. Itihara, () saka City Univ. Comment (M.I.) : dated bed probably belongs to sediment of Younger Terrace I, underlain by Paleo-Biwa group. For flora see Miki (1956).

\section{GaK-414. Kozuhata, 1}

$$
\begin{aligned}
& 30,000 \pm 1700 \\
& 28,050 \text { в.C. }
\end{aligned}
$$

Wood from silt and sand just below base of Younger Terrace II. 

race II.

Wood from sandy silt with pebhles, ca. $1 \mathrm{~m}$ below base of Younger Ter-

\section{Awaji-shinmachi series, Osaka}

Shells from Awaji-shinmachi Higashi-yodogawaku, Osaka City (34 ${ }^{\circ} 44^{\prime}$ $22^{\prime \prime} \mathrm{N}$ Lat, $135^{\circ} 30^{\prime} 47^{\prime \prime} \mathrm{E}$ Long), alt $2.0 \mathrm{~m}$. Marine shells of GaK-362 and freshwater shells of GaK-363 from below and above gravel layer $30 \mathrm{~cm}$ thick. Coll. and subm. 1963 by Hikotaro Kajiyama, Juso P. O. Comment (H.K.) : dates change from marine to freshwater conditions at mouth of swamp in central part of Kouchi. Other dates indicating similar change are given by GaK-168, 169 (Gakushuin I) and Osaka marine Layer series (Gakushuin II).

\section{GaK-362. Awaji-shinmachi, 1}

$$
2260 \pm 90
$$

Mya japonica and Anadara subcrenata, 7.10 to $7.50 \mathrm{~m}$ below surface.

\section{GaK-363. Awaji-shinmachi, 2}

$1610 \pm 80$

\section{A.D. 340}

Inversidens hirasei and I. japonensis 6.80 to $6.60 \mathrm{~m}$ below surface, associated with Sueki and Hajiki pottery.

\section{Mt. Myoko series}

Wood and charcoal from volcanic deposit of Mt. Myoko. Coll. and subm. 1963 by Tsutomu Utashiro, Univ. of Niigata.

\section{GaK-409. Myoko, Niigata \\ $19,600 \pm 600$ \\ 17,650 в.с.}

Wood from Myoko, Nakakubikigun, Niigata Prefecture ( $36^{\circ} 54^{\prime} 6^{\prime \prime} \mathrm{N}$ Lat. $138^{\circ} 16^{\prime} 40^{\prime \prime} \mathrm{E}$ Long), in volcanic mudflow of Mt. Myoko, overlain by terrace gravel $4 \mathrm{~m}$ thick. Comment (T.U.) : dates a big eruption of Mt. Myoko.

GaK-411. Osawa-shinden, Arai City

Peat from Osawa-shinden, Arai City, Niigata Prefecture $\left(36^{\circ} 57^{\prime} 12^{\prime \prime} \mathrm{N}\right.$ Lat, $138^{\circ} 16^{\prime} 16.9^{\prime \prime} \mathrm{E}$ Long), from base of pyroclastics ca. $4 \mathrm{~m}$ thick. Comment (T.U.) : dates most recent central volcanic cone.

\section{GaK-456. Himegawara, Arai City, 1 \\ $20,200 \pm 800$ \\ 18,250 в.с.}

Wood from depth $5.25 \mathrm{~m}$ Himegawara, Arai City, Niigata Prefecture $\left(37^{\circ} 0^{\prime} 5^{\prime \prime} \mathrm{N}\right.$ Lat, $138^{\circ} 16^{\prime} 30^{\prime \prime} \mathrm{E}$ Long), in peaty sand overlain by mudflow of Myoko Volcano.

\section{GaK-457. Himegawara, Arai City, 2 \\ $17,900 \pm 450$ \\ 15,950 в.с.}

Wood from site of GaK-456, $3.5 \mathrm{~m}$ below surface of mudflow. Comment (T.U.) : mudflow ca. $5 \mathrm{~m}$ thick at Himegawara is possibly from eruption of Myoko dated by GaK-409, this series. 


\section{Takata Plain series, Niigata}

Wood from Takata Plain alluvium. Coll. and subm. 1963 by Tsutomu ltashiro. Comment: see GaK-280 and 281 (Gakushuin III).

\section{GaK-412. Nakamachi Takata City}

$4950 \pm 150$

Wood from boring at Nakamachi, Takata City, Niigata Prefecture $137^{\circ}$ $7^{\prime} \mathrm{N}$ Lat, $138^{\circ} 14^{\prime}$ E Long), in alluvial sand, $8 \mathrm{~m}$ below surface.

\section{GaK-458. Hara, Arai City}

$1580 \pm 100$

Wood from Hara, Arai City, Niigata Prefecture $\left(37^{\circ} 0^{\prime} \mathrm{N}\right.$ Lat, $138^{\circ} 12^{\prime}$ E Long), in mudflow (?), 3 m below surface.

\section{GaK-459. Koizumo, Arai City}

Wood from Koizumo, Arai City, Niigata Prefecture $\left(37^{\circ} 1^{\prime}\right.$ N Lat, $138^{\circ}$ $15^{\prime} 30^{\prime \prime}$ E Long), in sand, $3.30 \mathrm{~m}$ below surface.

\section{Mt. Fuji series}

Samples are related to the eruption of Mt. Fuji. For former datings see ()sawa series (Gakushuin I) and Mt. Fuji series (Gakushuin II).

\section{GaK-391. Fujimiya}

Charcoal from road cut, SW flank of Mt. Fuji, Fujimiya, Shizuoka Prefecture ( $35^{\circ} 9^{\prime} \mathrm{N}$ Lat, $138^{\circ} 43^{\prime} \mathrm{E}$ Long), alt $1610 \mathrm{~m}$, in pyroclastics underlain by lava flow. Coll. and subm. 1963 by Hiroshi Machida, Tokyo Metropol. Univ. Comment (H.M.) : date is maximum for Osawa lapilli. Minimum is $2470 \pm 70$ (GaK-134, Gakushuin I) (see Machida, 1964).

\section{GaK-442. In-no, Gotemba}

Charcoal from part of charred tree trunk (diam ca. $1 \mathrm{~m}$ ) in lava, In-no, Gotemba, Shizuoka Prefecture ( $35^{\circ} 17^{\prime} 44^{\prime \prime}$ N Lat, $138^{\circ} 51^{\prime} 12^{\prime \prime}$ E Long), alt $680 \mathrm{~m}$, from lava flow near surface. Coll. and subm. 1963 by Ikuo Huzimura, Mt. Fuji Meteorological Observatory. Comment (I.F.) : dates In-no Marubi lava flow.

\section{Ōshima series}

Wood and peaty clay in volcanics of Ōshima Izu. Comment: dates give time scale of history of Ōshima Volcano (Nakamura, 1960, 1961) and of secular variation of geomagnetic field (Nagata et al., 1963).

GaK-351a. ōshima, Izu, 1

$$
\begin{array}{r}
1330 \pm 90 \\
\text { A.D. } 620
\end{array}
$$

Wood (Acer mono Maximowocz, id. F. Yamauchi) from beach cliff of Nomashi, Ōshima $\left(34^{\circ} 44^{\prime} 4^{\prime \prime} \mathrm{N}\right.$ Lat, $139^{\circ} 21^{\prime} 26^{\prime \prime} \mathrm{E}$ Long), in mudflow of $\mathrm{S}_{2}$ member, ca. $2.5 \mathrm{~m}$ thick, $5 \mathrm{~m}$ below surface. Coll. 1963 and subm. by Kazuaki Nakamura, Univ. of Tokyo. Comment (K.N.) : dates $\mathrm{S}_{2}$ and also caldera at summit of Ōshima Volcano. Estimated age of $\mathrm{S}_{2}$ by associated pottery is A.D. 200. Historical literature (Nihon Shoki) described an eruption at A.D. 684 . 


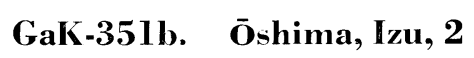

Innermost part of wood sample of GaK-35la.

GaK-353. '̄ shima, Izu, 3
$1350 \pm 100$ A.D. 600

$1500 \pm 160$

A.D. 450

Wood from same site and layer of GaK-351a. Coll. and subm. 1963 by K. Nakamura.

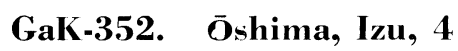

$2420 \pm 150$ 470 в.c.

Peaty clay from $\mathbb{W}$ margin of big road cut, $\mathrm{SW}$ corner Ōshima Is. $\left(34^{\circ}\right.$ $41^{\prime} 42^{\prime \prime} \mathrm{N}$ Lat, $139^{\circ} 22^{\prime} 18^{\prime \prime} \mathrm{E}$ Long), overlain by scoria $20 \mathrm{~cm}$ thick. Coll. and subm. by K. Nakamura. Comment (K.N.) : dates tenth major eruption prior to that of $S_{2}$.

\section{GaK-476. Okada, Ōshima, Izu}

$21,230 \pm 720$

Wood (Alnus sieboldiana Matsumura, id. by T. Watari) from coastal cliff, W of ( kada Harbor, Ōshima ( $34^{\circ} 47^{\prime} \mathrm{N}$ Lat, $139^{\circ} 23^{\prime} \mathrm{E}$ Long), in mudflow of Senzu tuff breccia (Nakamura, 1961). Coll. and subm. 1964 by Naoki Isshiki, Geol. Survey of Japan. Comment (N.I.) : probahly dates beginning of eruption of Ōshima Volcano.

\section{GaK-387. Chichibu, Saitama Prefecture $\quad 17,300 \pm 300$}

Wood from $4.3 \mathrm{~m}$ below surface, Une Yokomise, Chichibu, Saitama Prefecture $\left(35^{\circ} 59^{\prime} 0^{\prime \prime} \mathrm{N}\right.$ Lat, $139^{\circ} 6^{\prime} 3^{\prime \prime} \mathrm{E}$ Long), ca. $2 \mathrm{~m}$ below top of gravel. sand and clay layer, overlain by $2 \mathrm{~m}$ terrace deposit. Coll. and subm. $1963 \mathrm{by}$ Mankichi Horiguchi, Univ. of Saitama. Comment (M.H.) : surface of terrace contains artifacts of Middle Jomon culture.

GaK-382. Watari, Fukushima

Wood from clay layer, Hirauchi, Watari, Fukushima City $\left(37^{\circ} 44^{\prime} 20^{\prime \prime} \mathrm{N}\right.$ Lat, $140^{\circ} 29^{\prime} 17^{\prime \prime}$ E Long), overlain by volcanic ash, sand and gravel $5.5 \mathrm{~m}$ thick. Coll. and subm. 1963 by Tadashi Yoshida, Adachi High School. Comment: clay overlain by alluvium of Fukushima basin was dated by GaK-275, $21,000 \pm 850$ (Gakushuin III).

\section{Towada pumice flow series}

Peat and wood from Towada pumice flow occurring near Kosaka Mine, Kosakamachi, Akita Prefecture. Coll. and subm. 1963 by Hiroyuki Sato, Geol. Survey of Japan. Comment (H.S.) : dates Layers L, M, and U of pumice flow related to Towada Caldera (Oike, 1964). See also Gak-205, 226, and 227 (Gakushuin II).

GaK-384. Towada, 1

Peat from just below Layer L of Towada pumice flow $\left(40^{\circ} 20^{\prime} \mathrm{N}\right.$ Lat, $140^{\circ}$ 44' 51.4" E Long), $2 \mathrm{~m}$ below surface of ground.

\section{GaK-385. Towada, 2}

Wood from site of GaK-384, just below hase of Layer M of Towada pumice flow, $6 \mathrm{~m}$ below surface of ground. 
GaK-460. Towada, 3

$10,400 \pm 220$

8450 в.c.

Charred wood from U of Towada pumice flow ( $39^{\circ} 19^{\prime} 53^{\prime \prime} \mathrm{N}$ Lat, $140^{\circ}$ 44' 53.4" E Long), $3 \mathrm{~m}$ below surface of ground.

II. ARCHAEOLOGIC SAMPLES

\section{A. North America}

\section{GaK-405. Coffey County, 14CF301, Kansas}

A.D. 1020

$930 \pm 150$

Charcoal from fill of a pit in floor of House 2, Site 14CF301, Coffey County, Kansas $\left(38^{\circ} 15^{\prime} 35^{\prime \prime} \mathrm{N}\right.$ Lat, $95^{\circ} 47^{\prime} 22^{\prime \prime} \mathrm{W}$ Long). Coll. and subm. 1963 by T. A. Witty, Kansas State Hist. Soc. Comment (T.A.W.) : dates construction of this early Central Plains Phase type lodge (Witty, 1963).

\section{Williamson series, Coffey County}

Samples from Williamson site 14CF330, a multiple component site with occupations representing the Archaic, Early and Middle Ceramic Periods, Coffey County, Kansas ( $38^{\circ} 16^{\prime} 57^{\prime \prime}$ N Lat, $95^{\circ} 52^{\prime} 44^{\prime \prime} \mathrm{W}$ Long). Coll. and subm. 1963 by T. A. Witty. Comment (T.A.W.) : dates an Archaic occupation in this site and two associated burials (Witty, 1963).

GaK-406. 14CF330, 1

$3500 \pm 100$

Charcoal from level representing Archaic occupation.

GaK-407. 14CF330, 2

1550 в.c.

Charcoal from near Burial No. 2 in Archaic level.

\section{GaK-408. Coffey County, 14CF332, Kansas}

$3600 \pm 190$

1650 в.с.

Charcoal from occupation zone at Gilligan Site, 14CF332, camp site belonging to early Ceramic Period, Coffey County, Kansas $\left(38^{\circ} 16^{\prime} 12^{\prime \prime} \mathrm{N}\right.$ Lat, $95^{\circ} 56^{\prime} 56^{\prime \prime} \mathrm{W}$ Long). Coll. and subm. 1963 by T. A. Witty. Comment (T.A.W.) : dates occupation of site. Sample was coll. from same level as a Hopewellian potsherd (Witty, 1963).

\section{B. Japan}

\section{Hakui series, Ishikawa Prefecture}

Wood from Tsugibamachi, Hakui City, Ishikawa Prefecture $\left(36^{\circ} 5^{\prime} 50^{\prime \prime}\right.$ $\mathrm{N}$ Lat, $136^{\circ} 47^{\prime} 28^{\prime \prime}$ E Long), just below layer containing many earthenwares of late and middle Yayoi Period. Coll. and subm. 1963 by Norio Fuji, Univ. of Kanazawa.

\section{GaK-389. Hakui, Trench II}

From Tr. II, $2 \mathrm{~m}$ below surface.

GaK-390. Hakui, Trench IV

From Tr. IV, 2 m below surface.

$$
\begin{array}{r}
1500 \pm 100 \\
\text { A.D. } 450 \\
1380 \pm 90 \\
\text { A.D. } 570
\end{array}
$$




\section{Orimoto Shell Mound series, Yokohama}

Shells from Orimoto Shell Mound, Kohoku-ku, Yokohama $\left(35^{\circ} 30^{\prime} \mathrm{N}\right.$ Lat, $139^{\circ} 40^{\prime} \mathrm{E}$ Long), 30 to $60 \mathrm{~cm}$ below surface. Coll. and subm. 1963 by N. Kanai, Waseda Univ. Comment (N.K.) : associated earthenwares are of early Jomon type. Moroiso A, B and Hansai-chikkanmon are abundant.

GaK-379a. Orimoto, $-30 \mathrm{~cm}$

Shells from $31 \mathrm{~cm}$ below surface.

GaK-379b. Orimoto, $-60 \mathrm{~cm}$

Shells from $60 \mathrm{~cm}$ below surface.

\section{Australia}

\section{GaK-370. Seelands, N.S.W.}

$$
1210 \pm 30
$$

\section{A.D. 740}

Charcoal from rock shelter at Seelands via Grafton. New South Wales (29 35' $20^{\prime \prime}$ S Lat, $152^{\circ} 54^{\prime} 30^{\prime \prime}$ E Long), from Level IIIA. Coll. and subm. 1963 by I. McBryde, Univ. of New England. Details of site described by McBryde (1962). Comment: differs from previous measured date of 1920 B.C. (V-11, see McBryde, 1961), but agrees with GaK-372.

\section{Whiteman Creek series}

Charcoal from occupation deposit of a rock shelter, Site III, at Whiteman Creek, via Grafton, New South Wales (29 $35^{\prime} 30^{\prime \prime} \mathrm{S}$ Lat, $152^{\circ} 51^{\prime} 15^{\prime \prime} \mathrm{E}$ Long). Coll. 1962 and subm. by I. McBryde.

\section{GaK-371. Whiteman Creek, Site III, L-I}

$$
\begin{array}{r}
310 \pm 100 \\
\text { A.D. } 1640
\end{array}
$$

Charcoal from ca. 4 in. below surface of Level L, ca. 9 in. deep, containing animal bone, shells, but few artifacts. Comment (I.M.) : dates most recent period of occupation at site.

\section{GaK-372. Whiteman Creek, Site III, L-VI,a \\ $1640 \pm 120$}

Charcoal in brown soil forming upper stratigraphic level of deposit at entrance of shelter. Comment (I.M.) : level rich in artifacts, predominantly uniface pebble tools, similar to those from Level IIIA of Seelands rock shelter. See GaK-370.

\section{GaK-373. Whiteman Creek, Site III, L-VI,b}

$$
1870 \pm 140
$$

Charcoal from dark patch of soil in Level VI. Comment (I.M.) : approx. same age as GaK-372 was expected.

\section{Wombah Midden series}

Samples from shell midden deposit at Wombah near Iluka, $8 \mathrm{mi}$ W of mouth of Clarence River, New South Wales (29 $22^{\prime} \mathrm{S}$ Lat, $153^{\circ} 17^{\prime}$ E Long). Coll. and subm. 1963 by I. McBryde. 


\section{GaK-374. Wombah Midden, Site 1, L-IIA}

Charcoal obtained in excavation of midden deposit from Sq. (d). Layer IIA, depth below surface 7 to 19 in.

\section{GaK-375. Wombah Midden, Site 1, L-VIIId}

Charcoal from Sq. (d), Layer VIII, a layer of sandy brown soil representing earliest human occupation of site, 25 to $30 \mathrm{in}$. below surface, underlain hy sterile layer of white sand above sand-rock. Comment (I.M.) : dates earliest occupation level on site and may also contribute to study of geomorphology of area and strand-line change.

\section{GaK-376. Wombah Midden, Site 1, L-VIIIe}

Charcoal from Sq. (e), Layer VIII, 29 in. below surface. Comment (I.M.) : date should agree with GaK-375 from adjoining Sq. (d) .

\section{GaK-378. Yandama, N.S.W.}

Modern $<\mathbf{2 5 0}$

Charcoal from trial trench on open camp site on Yandama Station via Milparinka, New South Wales ( $29^{\circ} 43^{\prime} \mathrm{S}$ Lat, $141^{\circ} 17^{\prime} \mathrm{E}$ Long $), 3$ in. below surface. Associated implements include pirri points, geometric microliths, and tula adze slugs. Coll. and subm. 1963 by I. McBryde. Comment: fine charcoal powder was separated from brown soil by elutriation and treated with acid. (I.M.) : Open nature of site and possibility of later intrusion of charcoal make interpretation difficult. Implements of this type in the Murray Valley have been dated $4850 \pm 100$ B.P. (see Mulvaney, 1959) and $4290 \pm 140$ B.P. (see Tindale, 1930 and Mulvaney, 1961).

\section{Blaxland's Flat series}

Wood and charcoal collected during excavation of a group of burials in small rock shelter at Blaxland's Flat, near Grafton in Clarence Valley, northern New South Wales ( $29^{\circ} 53^{\prime} \mathrm{S}$ Lat, $152^{\circ} 52^{\prime}$ E Long). Burials had been wrapped in soft bark and wood. Coll. and subm. 1964 by I. McBryde.

\section{GaK-463. Blaxland's Flat, 1}

$1090 \pm 60$

Half-charred hark from 2 in. above floor of shelter, on $\mathrm{N}$ edge of burial group.

GaK-464. Blaxland's Flat, 2

$1230 \pm 50$

Charcoal and wood below bones of the burials.

\section{Curracurrang, Royal National Park series, N.S.W.}

Wood charcoal from occupation layers of coastal rock shelter at Curracurrang, Royal Natl. Park, New South Wales (34 ${ }^{\circ} 8^{\prime} 50^{\prime \prime} \mathrm{S}$ Lat, $151^{\circ} 6^{\prime} 25^{\prime \prime}$ E Long). Coll. and subm. by J. V. S. Megaw, Univ. of Sydney. Comment (J.V.S.M.) : series is first obtained from Sydney area and the tripartite occupation compares in general with the Eloueran-Bondaian-Capertian sequence established by McCarthy for inland eastern New South Wales. For summary of sequence, see McCarthy (1961). 
GaK-393b. Curracurrang 10 L

Charcoal fragments from cutting 10, Level l, or bottom clayey weathered sandstone occupation layer, ca. 39 in. below surface. Coll. 1963. Comment (J.V.S.M.) : as with the following three estimations date should indicate age of oldest coastal N.S.W. stone industry.

\section{GaK-394a. Curracurrang 5 L}

$3880 \pm 150$

1930 в.c. 1962.

Charcoal fragments from cutting 5, Level L, 27 in. below surface. Coll.

\section{GaK-394b. Curracurrang 5 L}

$3000 \pm 120$

More charcoal fraoments from original collection of $\mathrm{CaK}-394$. Commen (K.K. \& J.V.S.M.) : from stratigraphical evidence the same age for GaK-393b, $394 \mathrm{a}$, and 394b was expected. Owing to very scattered nature of charcoal fragments in lowest Layer L, fragments having various ages may have been gathered over a wide area; thus dates only represent a mean for the level.

\section{GaK-482. Curracurrang 15 L}

$7450 \pm 180$

\section{0 в.c.}

Charcoal fragments from base of cutting 15, 45 in. below surface. Comment (J.V.S.M.) : date seems very old compared with GaK-393 and 394; there is no indication of stratigraphical break or change in industry. But compare $11,600 \pm 400$ в.P. for Noola Rock Shelter, New South Wales (GaK-334, (Gakushuin III).

\section{GaK-481. Curracurrang 10-15B}

$$
\begin{array}{r}
1580 \\
\text { A.D. } 370
\end{array}
$$

Charcoal from baulk between cuttings 10 and 15, Layer B, 27 in. below surface. Coll. 1964. Comment (J.V.S.M.) : this and date obtained from base of Layer B(2150 \pm 180 B.P., I-1135, Isotopes V) are the first confirmed for the microlithic/backed-blade Bondaian industry, features of which are present at Seelands, Layer 2, dated $910 \pm 80$ в.P. (V-10, McBryde, 1961). NPL-32 (NPL I) gave $2550 \pm 90$ B.P. for comparable microlithic industry from upper level of Kenniff Cave, south central Queensland (Mulvaney, 1962). Compare the range of $4850 \pm 100(\mathrm{NZ}-456 / 1)$ to $3870 \pm 85$ (P-309, Pennsylvania V) for geometric microliths from Fromm's Landing, South Australia (Mulvaney, $1961)$.

GaK-482. Curracurrang $15 \mathrm{M}$, a

Modern $<\mathbf{2 0 0}$

Charcoal from cutting 15, Layer M, most recent level of occupation of the site, ca. 9 in. below surface. Coll. 1963.

\section{GaK-483. Curracurrang $15 \mathrm{M}, \mathrm{b}$}

Modern $<230$

Second sample as GaK-482. Comment (J.V.S.M.) : hoth GaK-482 and 483 came from upper, shell midden layer containing edge-ground axes, a simple flake industry and so-called 'fish-hood files' presumed to mark last stage of aboriginal occupation in Sydney area. Dates confirm this view. 


\section{Bevilaqua series}

Wood charcoal and shell samples from open site at Bevilaqua Cliffs, on coast W of Millicent, Lower South East Province of South Australia $\left(37^{\circ} 35^{\prime}\right.$ S Lat, $140^{\circ} 8^{\prime} \mathrm{E}$ Long). Coll. and subm. by P. S. Hossfeld, Univ. of Adelaide. Comment (P.S.H.) : dates two occupation sites and recent shoreline changes and coastal aeolianite deposits.

\section{GaK-397. Bevilaqua, A}

$8250 \pm 60$

Wood charcoal from upper part of Terra Rossa. Coll. 1961.

\section{GaK-423. Bevilaqua, $C$}

$$
6300 \text { B.c. }
$$

Marine shells from top of Terra Rossa. Coll. 1961.

GaK-398. Bevilaqua, D

Wood charcoal from black sand layer underlain by Terra Rossa. Coll. 1961.

\section{GaK-422. Bevilaqua, F}

$$
820 \pm 90
$$

Marine shells from same horizon as GaK-398. Coll. 1963.

\section{Mt. Burr Rock Shelter series}

Wood charcoal from Mt. Burr Rock Shelter, E of Millicent in Lower South East Province of South Australia ( $37^{\circ} 37^{\prime} \mathrm{S}$ Lat, $140^{\circ} 30^{\prime} \mathrm{E}$ Long). Coll. 1963 and subm. by P. S. Hossfeld. Charcoal fragments are sifted from sand, ashes and occupational debris.

\section{GaK-424. Burr, A}

Charcoal from 5 to $12 \mathrm{in.} \mathrm{helow} \mathrm{floor} \mathrm{of} \mathrm{Rock} \mathrm{shelter.}$

\section{GaK-425. Burr, B}

Charcoal from 12 to 24 in. below floor.

\section{GaK-426. Burr, C}

Charcoal from 24 to $48 \mathrm{in}$. below floor.

\section{GaK-428. Burr, D}

$$
\begin{array}{r}
320 \\
\text { A.D. } 1630
\end{array}
$$$$
\text { A.D. } 1570
$$

$$
380 \pm 90
$$

$1020 \pm 40$ A.D. 930

$\mathbf{7 0 3 0} \pm 40$

5080 в.C.

Charcoal from sparsely scattered charcoal fragments in sandy horizon helow level of Burr C.

\section{GaK-427. Burr, E}

$7450 \pm 270$

Charcoal from same horizon as Burr D.

GaK-429. Burr, F

Charcoal from 132 to 144 in. below floor. Comment (P.S.H.) : dates earliest known human occupation of the district. 


\section{Island of Hawaii series}

Charcoal from Puu Ali’i site H 1. South Point, Kau Is. of Hawaii $\left(18^{\circ}\right.$ $54^{\prime} 45^{\prime \prime}$ N Lat, $155^{\circ} 40^{\prime} 35^{\prime \prime}$ W Long). Coll. and subm. by K. P. Emory, Bishop Mus. Comment: see Gak-153 (Gakushuin I). M-863A (Michigan IV), and Hawaii series (Groningen V). See Emory (1962) for discussion.

GaK-256. Puu Alii, 1

Coll. 1953 from Sq. D9, 6 to 12 in. depth.

GaK-257. Puu Alii, 2

Coll. 1953 from Sq. I'4, 18 to 35 in. depth.

GaK-258. Puu Alii, 3a

Coll. 1955 from Sq. I'6, 4 to 6 in. depth.

GaK-290. Puu Alii, 3b

Coll. 1955 from same position as GaK-258.

GaK-259. Puu Alii, 4

Coll. 1955 from Sq. I'13, 13 to 21 in. depth.

GaK-260. Puu Alii, 5a

Coll. 1955 from Sq. J13, 16 to 23 in. depth.

GaK-291. Puu Alii, 5b

Coll. 1955 from same position as Gak-260.

$$
\begin{aligned}
575 & \pm 135 \\
\text { A.D. } 1375 & \\
680 & \pm \mathbf{3 6 0} \\
\text { A.D. } 1270 & \\
2250 & \pm \mathbf{2 5 0} \\
\mathbf{3 0 0} \text { в.C. } &
\end{aligned}
$$

$$
\begin{array}{r}
\text { Modern }<320 \\
710 \pm 170 \\
\text { A.D. } 1240 \\
\text { Modern }<400 \\
480 \pm 110 \\
\text { A.D. } 1470
\end{array}
$$

Modern $<220$

GaK-303. Haleakala peak, Is. of Maui

Charcoal from $\mathrm{N}$ fireplace in a shelter (just below peak) at Haleakala peak, summit $8432 \mathrm{ft}$ elevation $\left(20^{\circ} 12^{\prime} 21^{\prime \prime} \mathrm{N}\right.$ Lat, $156^{\circ} 11^{\prime} 26^{\prime \prime} \mathrm{W}$ Long). Coll. and subm. 1962 by K. P. Emory. Comment (K.P.E.) : should date first use of this fireplace.

\section{GaK-325. Holua Cave, Is. of Maui}

$$
\begin{array}{r}
1160 \pm 100 \\
\text { A.D. } 790
\end{array}
$$

Charcoal from bottom of care deposit in Holua Cave, inside crater of Haliakala, Is. of Maui $\left(20^{\circ} 44^{\prime} 42^{\prime \prime} N\right.$ Lat, $156^{\circ} 13^{\prime} 16^{\prime \prime} \mathrm{W}$ Long). Coll. and subm. 1962 by K. P. Emory. Comment (K.P.E.) : dates visit of first travelers through the crater.

\section{GaK-302. Hawaii-kai, Island of Oahu}

$$
\begin{array}{r}
620 \\
\text { A.D. } 1330
\end{array}
$$

Charcoal from Hawaii-kai site 0-5, Maunalua, Oahu, Hawaii $\left(21^{\circ} 17^{\prime} 40^{\prime \prime}\right.$ $N$ Lat, $157^{\circ} 42^{\prime} 15^{\prime \prime}$ W Long), from Sq. B4, ca. $50 \mathrm{~cm}$ depth. Coll. 1962 and subm. by W. Solheim, Univ. of Hawaii. Comment (W.S.) : should date first use of this shelter site. 
Tahiti, Society Islands series

Charcoal from Ana Fa'aana shelter site T9, Tahiti, Society Is. $\left(17^{\circ} 47^{\prime}\right.$ $30^{\prime \prime} \mathrm{S}$ Lat, $149^{\circ} 17^{\prime} 20^{\prime \prime} \mathrm{W}$ Long). Coll. 1961 and subm. by Y. H. Sinoto, Bishop Mus. Comment (Y.S.) : both samples were coll. from earth-ovens below water level.

GaK-212. Ana Fa'aana, TRC-6

$180 \pm 60$

From Sq. E7, 60 to $65 \mathrm{~cm}$ below surface.

Gak-216. Ana Fa'aana, TRC-5

Modern $<\mathbf{1 5 0}$

From Sq. D11. $74 \mathrm{~cm}$ below surface.

Afareaitu, Moorea, Society Islands series

Charcoal from Afareaitu site M5. Moorea, Society Is., $\left(17^{\circ} 32^{\prime} 22^{\prime \prime} \mathrm{S}\right.$ Lat, $149^{\circ} 46^{\prime} 43^{\prime \prime} \mathrm{W}$ Long). Coll. 1961 and subm. by Y. H. Sinoto. Comment (Y.H.S.) : GaK-218 is so far the oldest date in Society Is.

GaK-215. Afareaitu, TRC-7

Modern $<\mathbf{1 5 0}$

From test pit 16, 12 to $15 \mathrm{~cm}$ helow surface. Sample scattered on house foundation pavement.

$$
\begin{aligned}
940 & \pm 90 \\
\text { A.D. } 1010 &
\end{aligned}
$$

\section{GaK-218. Afareaitu, TRC-8}

From test pit $13,30 \mathrm{~cm}$ below surface.

GaK-217. Afareaitu, TRC-9

From test pit 12, $45 \mathrm{~cm}$ below surface.

$$
160 \pm 90
$$

\section{Opunohu Valley, Moorea, Society Islands series}

Charcoal from four sites in eastern portion of interior of Opunohu Valley on Moorea, Society Is. (17 $30^{\prime} \mathrm{S}$ Lat, $149^{\circ} 50^{\prime} \mathrm{W}$ Long) (Green, 1961) . Coll. and subm. 1963 hy R. C. Green, Univ. of Auckland.

GaK-364. ScMo 103c, Period III

Modern $<\mathbf{2 0 0}$

Charcoal from base of earliest layer in fill of large Period III oven, Site ScMo 103c, Sq. D10. Comment (R.C.G.) : associated with Period III roundended assembly house occupation, presumably of European contact period, and is stratigraphically later than GaK-365.

GaK-365. SeMo 103e, Period II

$350 \pm 110$

Charred outer skin of coconut tree taken from black layer of Period II, Site ScMo 103c, Sq. D9. Comment (R.C.G.) : sample was derived from an earlier occupation used as a fill to build up area behind terrace wall before constructing stone pavement for assembly house. Date indicates age for earlier occupation at site and for presence of the coconut.

GaK-366. ScMo 158d, Period IIIb

Modern $<180$

Charcoal from post hole fill of round-ended assembly house, second building stage, Period IIIb, site ScMo 158b. Comment (R.C.G.) : shows that assembly house at this site and ScMo 103c were contemporaneous and late. 
GaK-367. ScMo 158d, Period I

Modern $<\mathbf{1 8 0}$

Charcoal from infilling of Period I pit between Sq. D2 and E2, site ScMo 158d. Comment (R.C.G.) : result appears too recent as sample is stratigraphically earlier than black layer of Period II, the fill on which the Period III assembly house is built.

GaK-368. ScMo 129, Layer I

Modern $<180$

Charcoal from firepit under foundations of coastal marae at $a h u$ end and belonging to Layer I. Comment (R.C.G.) : dates period just prior to actual construction of coastal marae and indicates marae is contemporaneous with assembly houses.

GaK-369. ScMo 163, Layer I

$350 \pm 100$

A.D. 1600

Charcoal from fill of Pit $\mathrm{P}$ at $\mathrm{S}$ end of inland marae, belonging to Layer I, SE corner of Sq. El. Comment (R.C.G.) : sample stratigraphically belongs to an occupation before the marae was built on this site.

\section{Island of Raiatea series}

Shells from Marae Taputapustea, Is. of Raiatea $\left(16^{\circ} 50^{\prime} 12^{\prime \prime} \mathrm{S} \mathrm{Lat}, 151^{\circ}\right.$ $20^{\prime} 20^{\prime \prime} \mathrm{W}$ Long). Coll. and subm. 1962 by K. P. Emory. Control shells were coll. from a beach at sampling site. Comment (K.P.E.) : GaK-299 date indicates the time of expansion of the marae.

\section{GaK-299. Taputapuatea, TRC-10a}

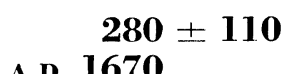

Scutarcopagia scobinata shells stuck in the holes of the coral uprights surrounding the marae platform.

\section{GaK-300. Taputapuatea, control, TRC-10b}

$$
\delta \mathrm{C}^{14}=+\mathbf{5 1} \pm \mathbf{1 1} \%
$$

Arca ventricosa shells were used. Comment: positive $\delta \mathrm{C}^{14}$ suggests bomb effect or other anomaly, and sample was not used as control.

\section{GaK-305. Paeao, TRC-12, Island of Maupiti Modern $<220$}

Charcoal from fireplace exposed by wave action on Motu Paeao, Is. of Maupiti ( $16^{\circ} 24^{\prime} 40^{\prime \prime} \mathrm{S}$ Lat, $152^{\circ} 12^{\prime} \mathrm{W}$ Long). Coll. and subm. 1962 by K. P. Emory and Y. H. Sinito.

\section{GaK-440. Aitape, New Guinea}

$5070 \pm 140$ 3120 в.c.

Wood charcoal from $\mathbb{W}$ of Aitape, Northern New Guinea ( $3^{\circ} 8^{\prime} \mathrm{S}$ Lat. $141^{\circ} 57^{\prime}$ E Long). Coll. 1962 and subm. by P. S. Hossfeld. Previously dated provisionally as Pleistocene. Comment (P.S.H.) : dates the entombment in an intertidal mud deposit of human cranial fragments with Australoid affinities. See Hossfeld (1949).

Date lists:

REFERENCES

Gakushuin I Kigoshi, Tomikura, and Fndo, 1962

Gakushuin II Kigoshi and Endo, 1963

Gakushuin III Kigoshi, Lin, and Endo, 1964

Groningen V Vogel and Waterbolk, 1964 
Isotopes V

Crane and Griffin, 1959

NPL I Callow, Baker, and Pritchard, 1963

Pennsylvania V Ralph and Stuckenrath, 1962

RIKEN I

Yamazaki, Hamada, and Fujiyama, 1964

Fimory, K. P., 1962, Additional radiocarbon dates from Hawaii and the Society Islands: Jour. Polynesian Soc., v. $71(1)$, p. 105-106.

Green, R. C., 1961, Moorean archaeology; a preliminary report: Man, v. 61, p. 169-173.

Hossfeld, P. S., 1949, The stratigraphy of the Aitape Skull: Royal Soc. S. Australia, Trans., v. 72, ,. 2.

Machida, H., 1964, Tephrochronological study of Volcano Fuji: Jour. of Geog., v. 73, no. 5 and no. 6.

MrBride, I., 1961, New radiocarbon dates for Australia: Antiquity, v. 35, p. 312-313.

1962, Archaeological field survey work in northern New South Wales: Oceania, v. 33 , no. 1, p. 12 .

McCarthy, F. D., 1961, Report on Australia and Melanesia: Asian Perspectives, v. 5, no. 2 , p. 141-155.

Miki, S., 1956, Remains of Pinus koraiensis S. et 2, and associated remains in Japan: Jour. Bot. Japan, v. 69 , no. 820 .

Mulvaney, I). J., 1959, Dating Australian prehistory: Nature, v. 184, p. 918.

1961. The stone age of Australia: Proc. Prehist. Soc., v. 27, p. 56-107.
1962, Adrancing frontiers in Australian archaeology: Oceania, v. 33, no. 2, 1. $135-138$

Nagata, T., Arai, Y., and Momose, K., 1963, Secular variation of the geomagnetic total force during the last 5000 years: Jour. Geophys. Research, v. 68, p. 5277-5281.

Nakamura, K., 1960, Stratigraphic studies of the pyroclsatics of Ōshima Volcano, Izu. deposited during the last fifteen centuries, I: Sci. Papers Colln. Gen. Educ. Univ. Tokyo, v. 10 , p. $125-145$.

1961, Stratigraphic studies of the pyroclastics of Ōshima Volcano, Izu, deposited during the last fifteen centuries, II: Sci. Papers Colln. Gen. Educ. Univ. Tokyo, v. 11, p. 281-319.

Oike, S., 1964, The absolute age of the Hachnohe pumice formation: Chikyu-Kagaku, v. 70, , $38-39$.

Tindale, N. B., 1930, Notes on some human remains in the Lower Murray Valley, South Australia; Records of South Australian Mus., v. 4, p. 145-218.

Witty, T. A., 1963, Excavations in the John Redmond Reservoir: Kansas Anthropol. Assoc. Newsletter, v. 9, no. 2. 